Article

\title{
Physico-Chemical and Antifungal Properties of a Trypsin Inhibitor from the Roots of Pseudostellaria heterophylla
}

\author{
Xixi Cai ${ }^{1,2}$, Xiaoli Xie ${ }^{2}$, Nanyan Fu ${ }^{1}$ and Shaoyun Wang ${ }^{2, *}$ \\ 1 The Key Lab of Analysis and Detection Technology for Food Safety of the MOE, College of Chemistry, \\ Fuzhou University, Fuzhou 350108, China; caixx_0123@163.com (X.C.); nanyan_fu@fzu.edu.cn (N.F.) \\ 2 Institute of Food and Marine Bio-Resources, College of Biological Science and Technology, \\ Fuzhou University, Fuzhou 350108, China; xiaoli18850225337@163.com \\ * Correspondence: shywang@fzu.edu.cn; Tel.: +86-591-2286-6375
}

Received: 28 July 2018; Accepted: 14 September 2018; Published: 18 September 2018

\begin{abstract}
Plant peptidase inhibitors play essential roles in the defense systems of plants. A trypsin inhibitor (PHTI) with a molecular mass of $20.5 \mathrm{kDa}$ was isolated from the fresh roots of the medicinal herb, Pseudostellaria heterophylla. The purification process involved ammonium sulfate precipitation, gel filtration chromatography on Sephadex G50, and ion-exchange chromatography on DEAE 650M. The PHTI contained 3.7\% $\alpha$-helix, $42.1 \% \beta$-sheets, $21.2 \% \beta$-turns, and 33\% disordered structures, which showed similarity with several Kunitz-type trypsin inhibitors. Inhibition kinetic studies indicated that PHTI was a competitive inhibitor, with a Ki value of $3.01 \times 10^{-9} \mathrm{M}$, indicating a high affinity to trypsin. The PHTI exhibited considerable stability over a broad range of $\mathrm{pH}(2-10)$ and temperatures $\left(20-70{ }^{\circ} \mathrm{C}\right)$; however, metal ions, including $\mathrm{Fe}^{3+}, \mathrm{Ba}^{2+}, \mathrm{Mn}^{2+}$, and $\mathrm{Al}^{3+}$, could inactivate PHTI to different degrees. Results of fluorescence spectroscopy and circular dichroism showed that $\mathrm{Fe}^{3+}$ could bind to TI with an association constant of $2.75 \times 10^{5} \mathrm{M}^{-1}$ to form a 1:1 complex, inducing conformation changes and inactivation of PHTI. In addition, PHTI could inhibit the growth of the phytopathogens, Colletotrichum gloeosporioides and Fusarium oxysporum, through disruption of the cell membrane integrity. The present study extended research on Pseudostellaria heterophylla proteins and makes PHTI an exploitable candidate as an antifungal protein for further investigation.
\end{abstract}

Keywords: trypsin inhibitor; Pseudostellaria heterophylla; fluorescence spectroscopy; circular dichroism; antifungal

\section{Introduction}

Natural peptidase inhibitors (PIs) are ubiquitous in living organisms, and have been largely described in plants [1]. Generally, PIs are particularly abundant in plant reproductive and storage organs, such as seeds and tubers, and amount to $1-15 \%$ of total soluble proteins in these tissues [2]. Previous reports have shown that PIs play essential roles in the defense systems of plants against attack by insects, fungi, and other pathogenic bacteria [2-4]. Besides, PIs have also been described as endogenous regulators of proteolytic processes and are known to be involved in many biological functions, such as anti-microbial infections, blood coagulation, platelet aggregation, and anti-carcinogenesis $[5,6]$.

PIs can be divided into four classes (serine-, metallo-, cysteine-, and aspartyl-PIs) based on the family of peptidases with which they interact. Serine-PIs are the largest group among the four classes, which are active against trypsin and/or chymotrypsin-like enzymes [7]. Serine-PIs are further typed into Kunitz, Bowman-Birk, cereal, and thaumati-like inhibitors [8-10], among which, the Kunitz-type 
trypsin inhibitors (KTIs) show the highest affinity to trypsin. KTIs commonly contain four cysteine residues forming two disulfide bridges and mainly consist of $\beta$-sheets with a molecular mass of about $20 \mathrm{kDa}$ [11]. Previous studies have revealed that KTIs have plasticity in their structure, which allows them to interact with peptidases with different specificities simultaneously [12].

The tuberous root of Pseudostellaria heterophylla (Caryophyllaceae) is a type of staple traditional Chinese medicine, which has been recorded in Chinese Pharmacopoeia with multiple medicinal effects, such as tonifying the spleen, nourishing vitality, moistening the lung, and improving appetite [13]. $P$. heterophylla is rich in polysaccharide [14,15], saponin [16], and cyclopeptides [17], and they exert multiple physiological functions, such as immunoregulation, antioxidant, anticancer, and so on. In contrast, although the protein content reaches up to $17 \%$ (dry weight), there are seldom reports on the proteins of the roots of P. heterophylla. A KTI with antifungal activity and a novel lectin isolated from $P$. heterophylla roots were reported [18]. However, the report mainly concerned the purification process and intrinsic trypsin inhibitory and hemagglutinating activity of the proteins. The description on the inhibition kinetic, structural characteristics, and antifungal mechanism were deficient. In the present report, a trypsin inhibitor (PHTI) was purified from the fresh roots of P. heterophylla. The physical-chemical properties of PHTI and the mechanism of the structural interaction between $\mathrm{Fe}^{3+}$ and PHTI were studied. Furthermore, the inhibition effects of PHTI against plant pathogens were demonstrated in this study, which make it an important candidate for further investigation on its role in plant defense.

\section{Results and Discussion}

\subsection{Purification of PHTI}

Chromatography was employed for the purification of trypsin inhibitor from the roots of P. heterophylla. As shown in Figure 1a, the dialyzed sample after $20-80 \%$ ammonium sulfate precipitation was divided into three fractions after Sephadex G-50 gel filtration chromatography and only fraction A2 displayed trypsin inhibitory activity (Figure 1a). Subsequently, fraction A2 was further fractionated by ion exchange chromatography on a DEAE-650M column (Figure 1b). Fraction A2-1 with 95\% trypsin inhibitory activity was collected, which presented a single band on SDS-PAGE under non-reducing and reducing conditions, with an apparent molecular mass of $20.5 \mathrm{kDa}$ (Figure 2a). Besides, the purified inhibitor was confirmed to be glycoprotein by SDS PAGE with periodic acid-schiff (PAS) staining (Figure 2b) and the carbohydrate content was determined to be $14.59 \pm 0.47 \%$ through the anthrone-sulfuric acid method. About $65.4 \mathrm{mg}$ of PHTI were obtained from $20 \mathrm{~g}$ of the fresh roots of P. heterophylla. The specific activity of the purified PHTI was determined to be $27,721.7 \mathrm{U} / \mathrm{mg}$, with a purification fold of 15.2 and a recovery of $39.4 \%$. The purification steps are summarized in Table 1.

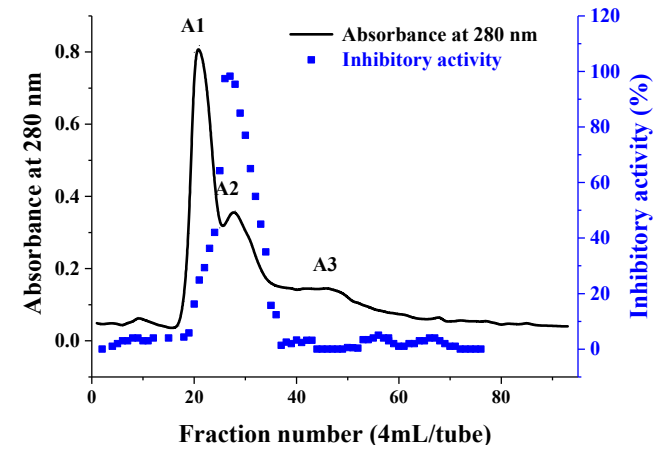

(a)

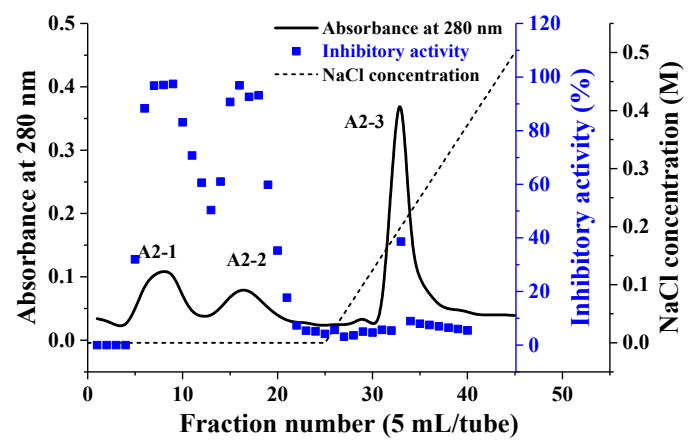

(b)

Figure 1. Purification of trypsin inhibitor (PHTI) from the roots of P. heterophylla. (a) Gel filtration chromatography on a Sephadex G50 column. (b) Ion exchange chromatography on a DEAE-650M column. 


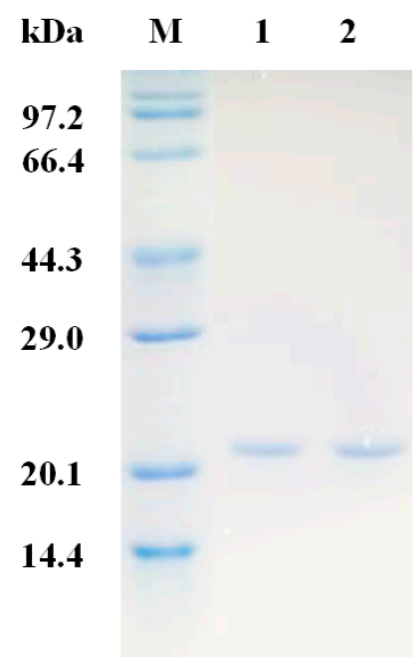

(a) (b)

Figure 2. SDS-PAGE of PHTI. (a) Lanes: M, molecular mass marker; 1 and 2, PHTI with and without addition of beta-mercaptoethanol stained by Coomassie brilliant blue. (b) PHTI stained by periodic acid-schiff (PAS) reagent.

Table 1. Summary of the purification process for PHTI and its trypsin inhibitory activity.

\begin{tabular}{cccccc}
\hline Fractions & $\begin{array}{c}\text { Total } \\
\text { Protein(mg) }\end{array}$ & $\begin{array}{c}\text { Total Trypsin } \\
\text { Inhibitory } \\
\text { Activity }\left(\times \mathbf{1 0}^{\mathbf{3}} \mathbf{U}\right)\end{array}$ & $\begin{array}{c}\text { Specific } \\
\text { Activity } \\
\mathbf{( U / m g )}\end{array}$ & $\begin{array}{c}\text { Purification } \\
\text { Fold }\end{array}$ & $\begin{array}{c}\text { Extraction } \\
\text { Yield (\%) }\end{array}$ \\
\hline Crude extraction ${ }^{1}$ & 2530.0 & 4600.3 & 1818.3 & - & 100.0 \\
$20-80 \%\left(\mathrm{NH}_{4}\right)_{2} \cdot \mathrm{SO}_{4}$ & 1259.3 & 3600.5 & 2859.1 & 1.6 & 78.3 \\
Sephadex G-50 & 190.6 & 2407.7 & $12,632.2$ & 6.9 & 52.3 \\
DEAE-650M & 65.4 & 1813.0 & $27,721.7$ & 15.2 & 39.4 \\
\hline
\end{tabular}

${ }^{1}$ Crude extraction was gained from $20.0 \mathrm{~g}$ of the fresh roots of P. heterophylla.

\subsection{Characterization of PHTI}

\subsubsection{N-Terminal Amino Acid Sequences of PHTI}

The N-terminal amino acids sequences of PHTI were determined to be Phe-Val-Val-Asp-LeuAsp-Gly-Asp-Pro-Leu (FVVDLDGDPL) by Edman degradation, and were then submitted to the NCBI-BLAST database for similarity analysis. Results showed that PHTI presented a high similarity to several plant Kunitz-type trypsin inhibitors, such as inhibitors from Leucaena leucocephala and Mucuna pruriens (Table 2).

Table 2. Analysis of the N-terminal sequence of Kunitz-type inhibitor from P. heterophylla roots.

\begin{tabular}{ccccc}
\hline Content & Source & Starting Amino Acid & Primary Sequences & Identity (\%) \\
\hline PHTI & Pseudostellaria heterophylla & 1 & F V V D L D G D P L & - \\
KTI & Leucaena leucocephala & 4 & - - V D L D G D P L & 80 \\
KTI & Mucuna pruriens & 26 & F V V D T D G D - - & 70 \\
KTI & Beta vulgaris subsp. vulgaris & 25 & F I L D I D G D P L & 70 \\
KTI & Glycine soja & 27 & F V L D N E G N P L & 60 \\
KTI & Inga vera & 3 & - V V D S D G E M L & 60 \\
\hline
\end{tabular}

The N-terminal sequences listed in Table 2 are from the NCBI database (https: / www.ncbi.nlm.nih.gov). The amino acids with background color mean that they are the same to the sequence of PHTI. 


\subsubsection{Circular Dichroism (CD) Spectrum Analysis}

The CD spectrum of PHTI was characterized by a weak positive peak near $225 \mathrm{~nm}$ and a negative peak around $203 \mathrm{~nm}$, respectively (Figure 3). PHTI was composed of 3.7\% $\alpha$-helix, $42.1 \% \beta$-sheets, $21.2 \% \beta$-turns, and 33\% disordered structures, as calculated by CDPro software. Similar inhibitors had been reported. A trypsin inhibitor from Cassia leiandra seeds was composed of $35 \%$-sheets, $14 \% \beta$-turns, and 50\% disordered structures [19], and the trypsin inhibitor from Acacia plumosa was composed of $42 \% \beta$-sheets, $21 \% \beta$-turns, and $37 \%$ of disordered structures [20]. Previous reports showed that KTIs typically possess few $\alpha$-helix structures and 12 antiparallel $\beta$-sheets connected by long loops [21]. Disordered structures might provide flexibility to certain inhibitors to inhibit enzymes of different classes [22]. Above all, PHTI was considered to belong to Kunitz-type trypsin inhibitors and held the massive $\beta$-sheets as structural homology.

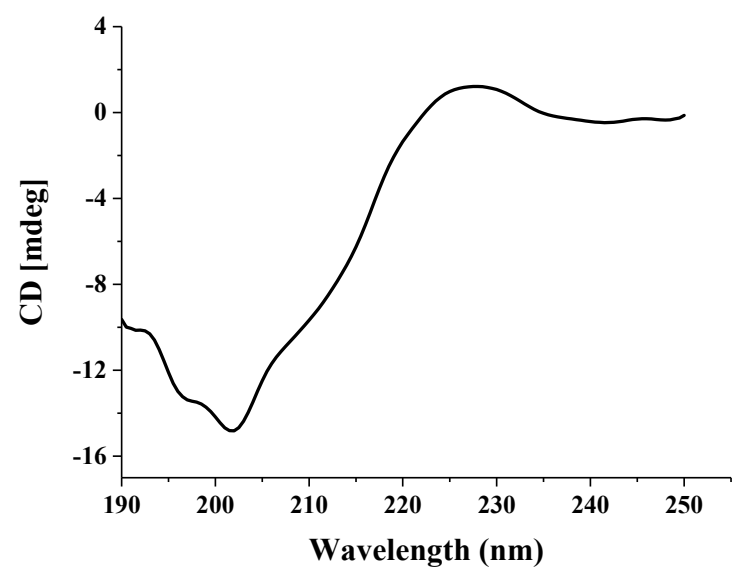

Figure 3. Circular dichroism spectrum of PHTI in distilled water.

\subsubsection{Trypsin Inhibition Kinetics of PHTI}

To determine the PHTI inhibition kinetic against trypsin, the Dixon and Lineweaver-Burk double reciprocal plot were employed. The initial rates of reaction of PHTI against trypsin using N $\alpha$-Benzoyl-DL-arginine 4-nitroanilide hydrochloride (BAPNA) as the substrate followed the Michaelis-Menten equation. The lines in the Dixon diagrams (Figure 4a) and Lineweaver-Burk (Figure $4 \mathrm{~b}$ ) were all intersected in the y-axis, indicating that PHTI was a competitive inhibitor, with a K $i$ value of $3.01 \times 10^{-9} \mathrm{M}$, which presented a high affinity between trypsin and PHTI. Kinetic studies on PHTI were in agreement with the reports for KTIs from the seeds of Inga laurina [23] and Butea monosperma [24], with a Ki of $6 \times 10^{-9} \mathrm{M}$ and $1.2 \times 10^{-9} \mathrm{M}$, respectively.

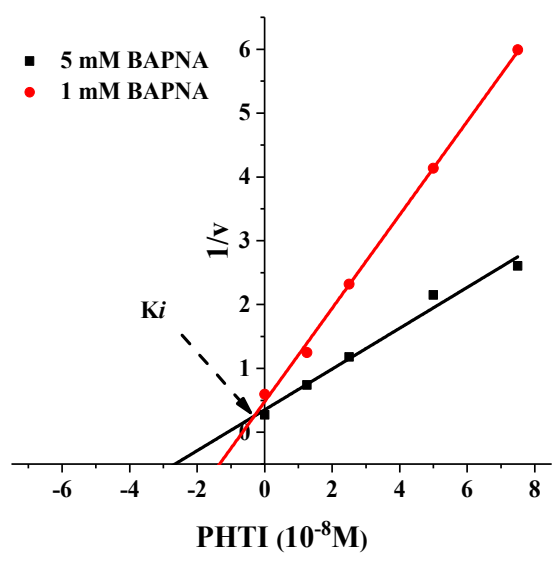

(a)

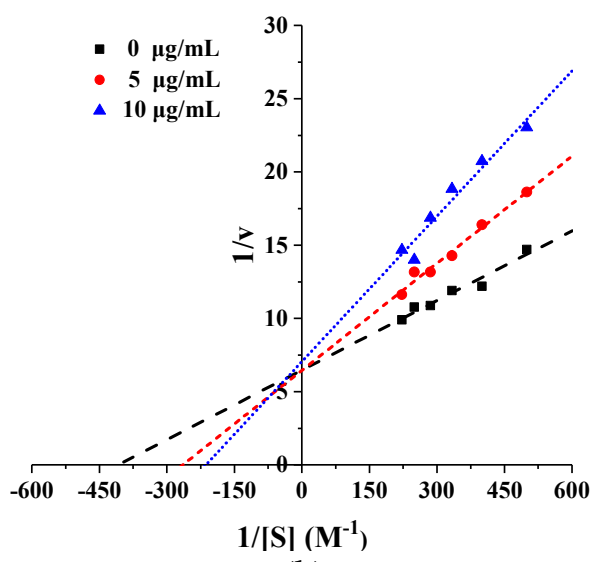

(b)

Figure 4. Inhibition kinetics of PHTI. (a) Dixon plot analysis. (b) Lineweaver-Burk plot analysis. 


\subsubsection{Stability of Inhibitory Activity against Trypsin}

Thermal and $\mathrm{pH}$ Stability

As shown in Figure 5a, trypsin inhibitory activity of PHTI was well retained after being incubated at $20-70{ }^{\circ} \mathrm{C}$ for $30 \mathrm{~min}$. However, the inhibitory activity was decreased by $36.5 \%$ at $80{ }^{\circ} \mathrm{C}$. Only $16.3 \%$ of the inhibitory activity remained after the $100^{\circ} \mathrm{C}$ treatment. The thermal stability of PHTI was similar to that of KTIs from Albizia amara Boiv [25] and Archidendron ellipticum seed [2]. In addition, the inhibitory activity of PHTI was not sensitive to $\mathrm{pH}$ over the range of 2-10 (Figure $5 b$ ). Similar results were reported for KTIs from Entada acaciifolia (Benth.) seeds [26], Catanduva seeds [27], and Inga laurina (SW.) Willd seeds [23].

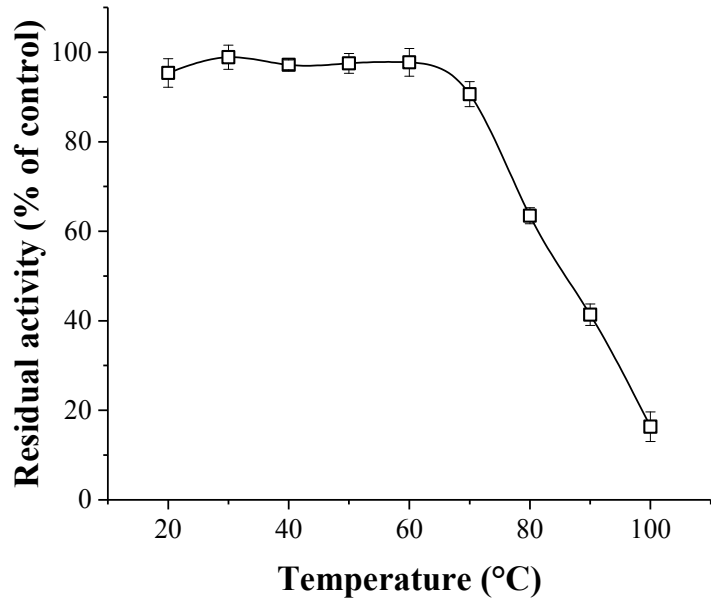

(a)

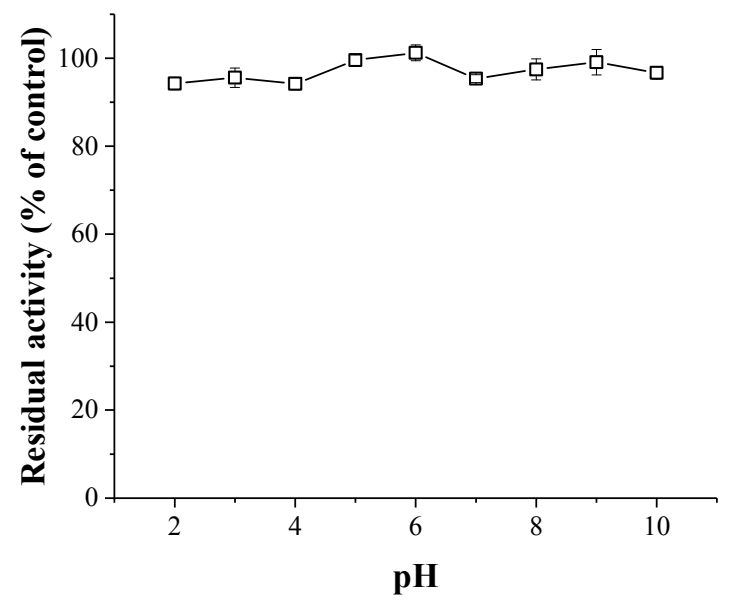

(b)

Figure 5. Thermal stability (a) and pH stability (b) of PHTI.

Effect of Metal Ions

Metal ions could induce changes of proteins in the conformation and thus affect the function and structure of the proteins [28]. The effects of metal ions on the trypsin inhibitory activity of PHTI were studied in the presence of different metal ions. As shown in Table 3, no notable changes in inhibitory activity were observed when concentrations of $\mathrm{Na}^{+}$and $\mathrm{K}^{+}$reached up to $20 \mathrm{mM}$. The addition of $\mathrm{Cu}^{2+}$ slightly enhanced the inhibitory activity of PHTI. $\mathrm{Ba}^{2+}, \mathrm{Zn}^{2+} \mathrm{Mn}^{2+}$, and $\mathrm{Al}^{3+}$ had negative effects on the trypsin inhibitory activity of PHTI, with a $40-60 \%$ loss of activity at $20 \mathrm{mM}$. Among the tested ions, $\mathrm{Fe}^{3+}$ presented the strongest inhibition effect. With the addition of $20 \mathrm{mM} \mathrm{Fe}^{3+}$, only $9.4 \%$ trypsin inhibitory activity remained. Similarly, the trypsin inhibitor, API, from Albizia amara Boiv showed enhanced activity with the addition of $\mathrm{Cu}^{2+}$ and reduced activity in the presence of $\mathrm{Mn}^{2+}, \mathrm{Ba}^{2+}$, and $\mathrm{Fe}^{3+}[25] . \mathrm{Al}^{3+}$ was also reported to inhibit the activity of trypsin inhibitor from Moringa oleifera leaves [29].

Table 3. Effect of metal ions on PHTI.

\begin{tabular}{|c|c|c|c|c|c|c|c|c|c|}
\hline $\begin{array}{l}\text { Metal Ions Conce } \\
\text { (mM) }\end{array}$ & ration & $\mathrm{AlCl}_{3}$ & $\mathrm{FeCl}_{3}$ & $\mathrm{BaCl}_{2}$ & $\mathrm{ZnCl}_{2}$ & $\mathrm{MnCl}_{2}$ & $\mathrm{CuCl}_{2}$ & $\mathrm{NaCl}$ & $\mathrm{KCl}$ \\
\hline \multirow{5}{*}{$\begin{array}{l}\text { Residual activity } \\
\text { (\% of control) }\end{array}$} & 0.1 & $94.6 \pm 1.2$ & $96.8 \pm 0.5$ & $99.8 \pm 1.7$ & $100.0 \pm 1.5$ & $100.4 \pm 0.5$ & $99.8 \pm 1.2$ & $99.1 \pm 0.7$ & $99.8 \pm 0.7$ \\
\hline & 1 & $82.3 \pm 1.5$ & $95.0 \pm 0.2$ & $97.9 \pm 1.0$ & $98.2 \pm 1.5$ & $99.8 \pm 0.2$ & $100.9 \pm 0.2$ & $99.8 \pm 0.2$ & $100.2 \pm 1.2$ \\
\hline & 5 & $65.8 \pm 1.2$ & $91.2 \pm 0.5$ & $95.5 \pm 1.1$ & $96.4 \pm 0.8$ & $97.3 \pm 1.0$ & $98.1 \pm 0.8$ & $99.2 \pm 0.6$ & $98.1 \pm 1.3$ \\
\hline & 10 & $63.9 \pm 3.0$ & $29.5 \pm 1.3$ & $77.8 \pm 1.2$ & $85.8 \pm 1.7$ & $84.4 \pm 1.5$ & $117.2 \pm 1.8$ & $97.5 \pm 0.5$ & $96.8 \pm 1.7$ \\
\hline & 20 & $60.5 \pm 0.2$ & $9.4 \pm 1.3$ & $40.5 \pm 1.4$ & $60.2 \pm 0.4$ & $67.6 \pm 0.6$ & $106.2 \pm 1.6$ & $98.8 \pm 1.0$ & $94.4 \pm 1.7$ \\
\hline
\end{tabular}

Values represent the mean $\pm \mathrm{SD}$ of three replicates. 


\subsubsection{Effect of $\mathrm{Fe}^{3+}$ on the Conformation Change of PHTI}

For further investigation of the mechanism of the $\mathrm{Fe}^{3+}$-mediated inhibition towards PHTI, both fluorescence spectroscopy and CD spectroscopy were conducted. As shown in Figure 6a, the intrinsic fluorescence intensity of PHTI increased significantly with the increase of the $\mathrm{Fe}^{3+}$ concentration, and a slight red shift of the maximum emission fluorescence peak (about $4 \mathrm{~nm}$ ) appeared. The synchronous fluorescence spectra of PHTI in the presence of $\mathrm{Fe}^{3+}$ are also shown in Figure 6. The synchronous fluorescence was characteristic of tyrosine residues (Tyr) and tryptophan residues (Trp) at $\Delta \lambda$ of 15 and $60 \mathrm{~nm}$ between the excitation and emission wavelengths, respectively [30]. The fluorescence intensities of both Tyr and Trp increased significantly with the addition of the $\mathrm{Fe}^{3+}$ solution (Figure $6 \mathrm{~b}, \mathrm{c}$ ), indicating a conformation change of PHTI and the exposure of tyrosine and tryptophan residues in the presence of $\mathrm{Fe}^{3+}$ [31]. Furthermore, an obvious red shift (about $22 \mathrm{~nm}$ ) of the maximum emission wavelength at the wavelength interval of $15 \mathrm{~nm}$ was observed, suggesting an increase in hydrophilicity around the tyrosine residues [31]. $\mathrm{Fe}^{3+}$ could bind to TI with an association constant of $2.75 \times 10^{5} \mathrm{M}^{-1}$ to form a 1:1 complex, according to the Stern-Volmer equation analysis.

Conformation changes of PHTI were analyzed by CD spectroscopy (Figure 6d). A negative peak appeared around $203 \mathrm{~nm}$ and a positive peak near $225 \mathrm{~nm}$ gradually shifted towards zero with the increase of $\mathrm{Fe}^{3+}$ concentrations. As the concentration of $\mathrm{Fe}^{3+}$ increased, the maximal ellipticity underwent a decline from 195 to $205 \mathrm{~nm}$. However, the proportions of $\alpha$-helix, $\beta$-sheets, $\beta$-turns, and disordered structures (calculated by CDPro) of PHTI in the presence of $\mathrm{Fe}^{3+}$ at various concentrations were highly consistent with PHTI (Data not shown), indicating that the addition of $\mathrm{Fe}^{3+}$ at the tested concentration had no effect on the secondary structure of PHTI. Therefore, we speculated that $\mathrm{Fe}^{3+}$ could mediate the inactivation of PHTI by changing the higher conformation rather than the secondary structure of PHTI.

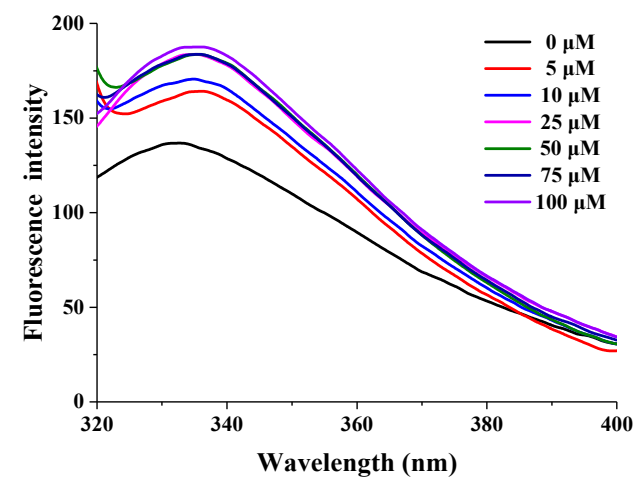

(a)

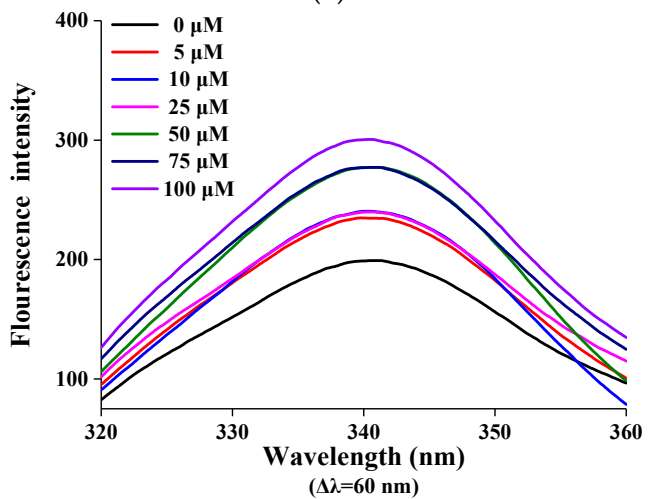

(c)

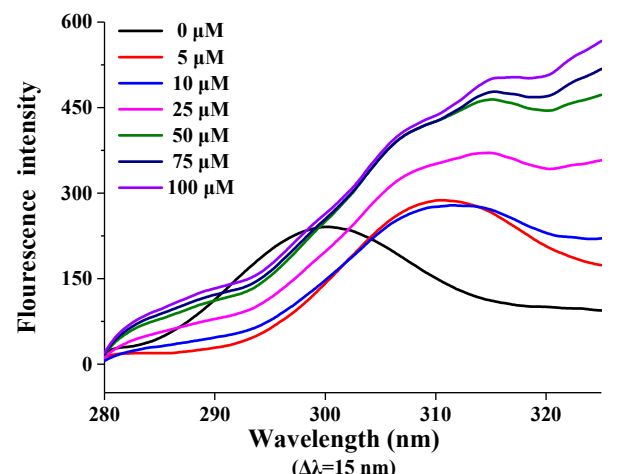

(b)

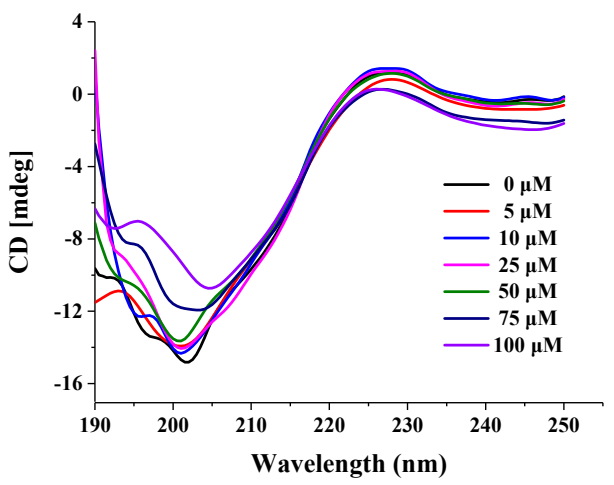

(d)

Figure 6. Intrinsic fluorescence spectra (a) and synchronous fluorescence spectra (b,c) of PHTI with $\mathrm{Fe}^{3+}(0,5,10,25,50,75$, and $100 \mu \mathrm{M}$, respectively). (d) Far-UV CD spectra of PHTI recorded in the presence of different $\mathrm{Fe}^{3+}$ concentrations in deionized water. 


\subsection{Antifungal Activity of PHTI}

PIs, serving as a kind of defense proteins in plants, have shown inhibition of plant pathogenic fungi. Fusarium oxysporum f.sp. cubense and Colletotrichum gloeosporioides Penz are two kinds of phytopathogens of $P$. heterophylla [32]. In this work, the antifungal activity of PHTI against C. gloeosporioides (Figure 7a) and F. oxysporum (Figure 7b) were evaluated. Compared with the control disk (1), disks with $0.1 \mathrm{mM}, 0.25 \mathrm{mM}$, and $0.5 \mathrm{mM}$ of PHTI showed obvious crescents, indicating the growth inhibition of fungi. As shown in Figure $7 \mathrm{c}, 0.5 \mathrm{mM}$ of PHTI could significantly lead to prolongation in the lag phase of $C$. gloeosporioides in $10 \mathrm{~h}$ and distinctly inhibit its growth. Trypsin inhibitors from different sources possess antifungal activity to different degrees. The antifungal activity of PHTI was comparable to the reported trypsin inhibitor from Blighia sapida seeds [33], while inhibitors from Psoralea corylifolia L. [34] and Albizia amara Boiv [25] exerted superior fungi inhibition effects at a magnitude of $100 \mu \mathrm{g} / \mathrm{mL}$. However, trypsin inhibitors from Chinese dull black soybeans [35] and Vigna mungo seeds [36] did not present any fungi inhibitory effects.

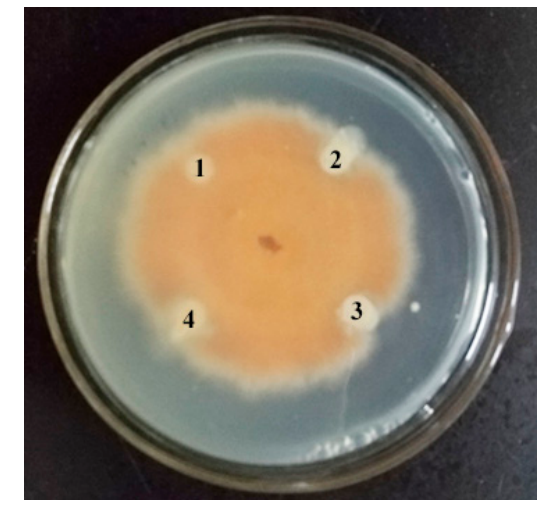

(a)

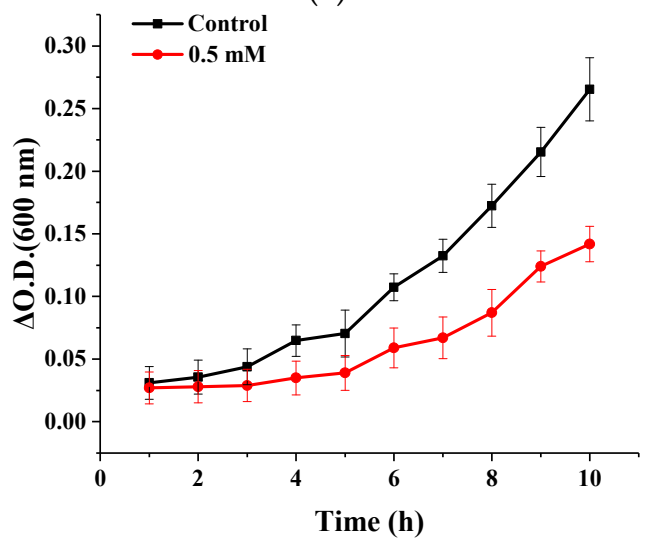

(c)

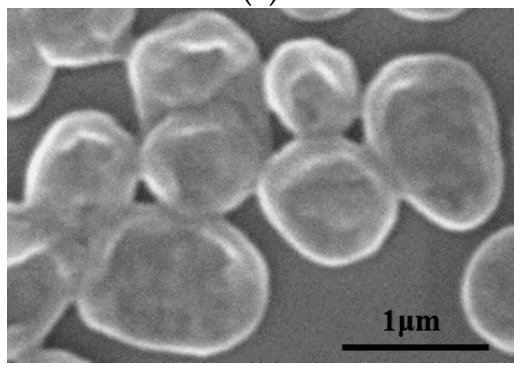

(e)

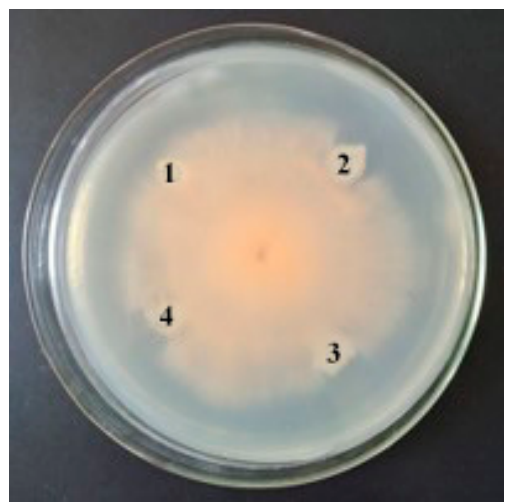

(b)

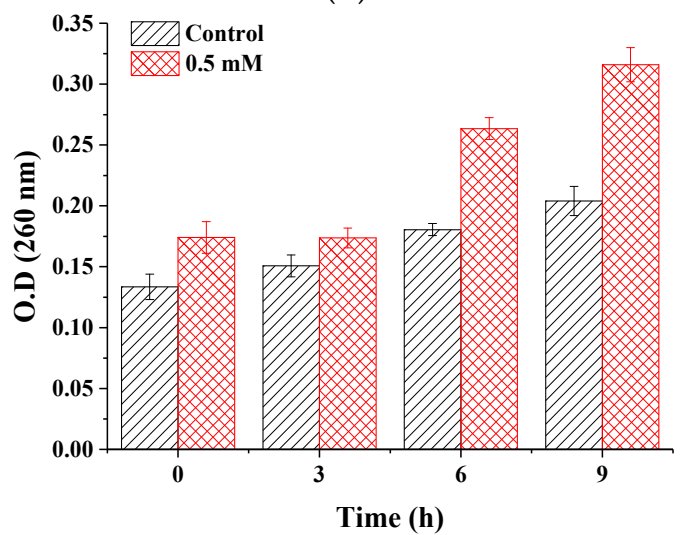

(d)

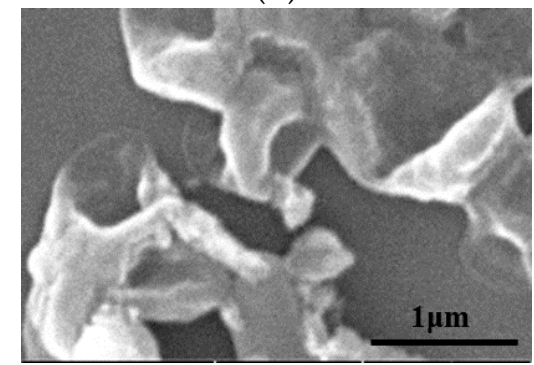

(f)

Figure 7. Cont. 

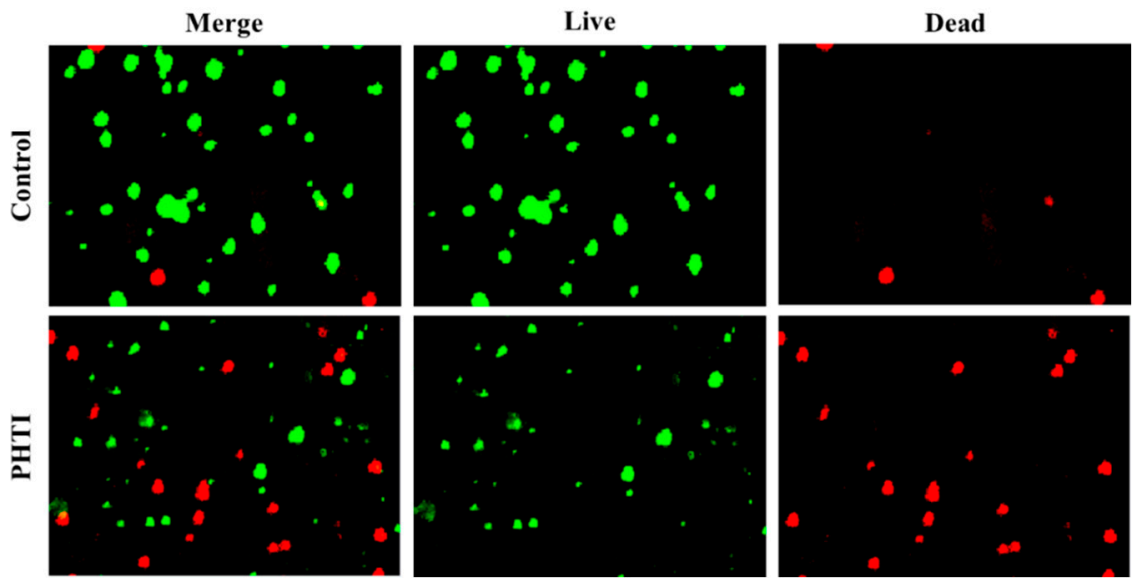

(g)

Figure 7. Antifungal activity of PHTI. Filter paper method for antifungals active against C. gloeosporioides (a) and F. oxysporum (b) ((1) Deionized water; (2) $0.1 \mathrm{mM}$ of PHTI; (3) $0.25 \mathrm{mM}$ of PHTI; (4) 0.5 mM of PHTI.) (c) Growth kinetics of $C$. gloeosporioides. (d) Total nucleotide leakage from C. gloeosporioides treated with $0.5 \mathrm{mM}$ of PHTI. (e,f) Scanning electron microscopy (SEM) images of C. gloeosporioides treated with 0 and $0.5 \mathrm{mM}$ of PHTI, respectively. (g) C. gloeosporioides viability visualized by fluorescence staining.

Hyphal membrane permeation is a common antifungal mode of action for many defensins [3]. To investigate the effects of PHTI on the cell membrane, C. gloeosporioides was treated with PHTI $(0.5 \mathrm{mM})$ and the nucleic acid contents in the culture medium were determined by the absorbance at $260 \mathrm{~nm}$. Results showed that the addition of $0.5 \mathrm{mM}$ PHTI significantly increased the extracellular nucleic acids contents, indicating damage of the cell membrane (Figure 7d). Scanning electron microscopy (SEM) experiments were conducted to directly observe the morphological changes of C. gloeosporioides. The control group (Figure 7e) displayed smooth surface and integral cell morphology, while the fungi treated with $0.5 \mathrm{mM}$ of PHTI were found to be clustered together without clear boundaries (Figure 7f). The cell membrane integrity changes were further confirmed by fluorescence staining. The viable bacterial cells with intact membranes were visualized as green by interaction of the Syto9 fluorescent dye. On the contrary, propidium iodide entered non-viable bacterial cells with porous membranes and combined with the bacterial nucleic acid, thus turning red fluorescence. Treatment with PHTI increased the proportion of red fluorescence (Figure 7g), further suggesting that PHTI could inhibit the growth of fungi through disrupting the cell membrane integrity. F. oxysporum treated with PHTI exhibited similar results (Data not shown).

\section{Materials and Methods}

\subsection{Materials}

Fresh roots of P. heterophylla were obtained from a P. heterophylla planting base in Zherong, Fujian, China. The fungal strains, F. oxysporum and C. gloeosporioides, were kindly provided by the Institute of Agricultural Bio-Resources Research, Fujian Academy of Agricultural Sciences, Fuzhou, China. Toyopearl DEAE-650M and Sephadex G50 Fine were purchased from TOSOH Co., Ltd. (Tokyo, Japan) and GE Healthcare (Gothenburg, Sweden), respectively. Trypsin and BAPNA were purchased from Shanghai Yuanye Bio-Technology Co., Ltd. (Shanghai, China). All other chemicals were of analytical grade and were purchased from Sinopharm Chemical Reagent Co., Ltd. (Shanghai, China).

\subsection{Purification of PHTI}

Fresh roots of P. heterophylla $(20 \mathrm{~g})$ were homogenized $(1: 7.5 \mathrm{w} / \mathrm{v})$ with Tris-HCl buffer $(50 \mathrm{mM}$ $\mathrm{pH}$ 7.4). After extraction at $4{ }^{\circ} \mathrm{C}$ for $12 \mathrm{~h}$, the homogenate was filtered through four layers of gauze 
and centrifuged at $10,000 \times g$ for $15 \mathrm{~min}$ at $4{ }^{\circ} \mathrm{C}$. The supernatant was subjected to ammonium sulfate precipitation. The fraction precipitated between $20 \%$ and $80 \%$ saturation was re-dissolved in a Tris- $\mathrm{HCl}$ buffer (50 mM, pH 7.4) and dialyzed against the same buffer at $4{ }^{\circ} \mathrm{C}$ for $24 \mathrm{~h}$.

The dialyzed sample was then applied to a Sephadex G50 column $(\Phi 1.6 \times 100 \mathrm{~cm})$ pre-equilibrated with the Tris- $\mathrm{HCl}$ buffer $(50 \mathrm{mM}, \mathrm{pH} 7.4)$. The column was eluted with the same buffer and the flow rate was $0.4 \mathrm{~mL} / \mathrm{min}$ and $10 \mathrm{~min} /$ tube. The absorbance at $280 \mathrm{~nm}$ and the trypsin inhibitory activities of the fractions were determined. At the later purification stage, anion-exchange chromatography was performed on a DEAE-650M column $(\Phi 1.6 \times 20 \mathrm{~cm})$ pre-equilibrated with the Tris- $\mathrm{HCl}$ buffer ( $50 \mathrm{mM}, \mathrm{pH}$ 7.4). The column was washed with the same buffer, and the absorbed fractions were eluted with a $0-0.5 \mathrm{M}$ linear gradient of $\mathrm{NaCl}$. The absorbance of the fractions was monitored and the eluted protein fractions with trypsin inhibitory activity were collected.

\subsection{Characterization of PHTI}

\subsubsection{SDS-PAGE}

SDS-PAGE was carried out in a $12.5 \%$ separating gel and $4.0 \%$ concentrating gel under reducing and non-reducing conditions according to the method of Laemmli and Favre [37]. Proteins were then stained with a $0.1 \%$ Coomassie brilliant blue R-250 solution and PAS solution, respectively [38].

\subsubsection{Protein N-Terminal Sequencing}

The purified protein was loaded to the SDS-PAGE and then mobilized onto a membrane of polyvinylidene difluoride (PVDF) by electroblotting. The N-terminal sequence of PHTI was determined by Edman degradation and analyzed by PPSQ-30 Data Processing (Applied Biosystems, Shanghai, China).

\subsubsection{Analysis}

CD spectra were used to evaluate the secondary structures and structural changes of proteins. The secondary structures of purified PHTI dissolved in deionized water with $\mathrm{Fe}^{3+}(0$ to $100 \mu \mathrm{M})$ were measured by Bio-Logic MOS-450 (Grenoble, France) at room temperature. The spectra were recorded from $190 \mathrm{~nm}$ to $250 \mathrm{~nm}$, with a response time of $2 \mathrm{~s}$ and scan speed of $100 \mathrm{~nm} / \mathrm{min}$. Quartz cuvettes of $1 \mathrm{~cm}$ were used. CDPro software was used to analyze the secondary structure and the data of all CD measurements were calculated in triplicate.

\subsubsection{Assay of Trypsin Inhibitory Activity}

The trypsin inhibitory activity was calculated by the residual hydrolysis activity of trypsin towards the substrate, BAPNA, according to the method of Birk [39]. $0.4 \mathrm{~mL}$ of PHTI and $2 \mathrm{~mL}$ of BAPNA $(40 \mathrm{mg} / \mathrm{mL}$ in $3 \mathrm{~mL}$ of dimethyl sulfoxide, diluted with $50 \mathrm{mM}$ Tris- $\mathrm{HCl}$ buffer containing $20 \mathrm{mM}$ $\mathrm{CaCl}_{2}$ to $\left.100 \mathrm{~mL}\right)$ were pre-incubated at $37^{\circ} \mathrm{C}$ for $10 \mathrm{~min}$, then $1 \mathrm{~mL}$ of trypsin $(0.2 \mathrm{mg} / \mathrm{mL}$ in $1 \mathrm{mM}$ $\mathrm{HCl}$ ) was added to the mixture. One unit of inhibitory activity (U) was defined as a decrease of 0.01 of absorbance at $410 \mathrm{~nm}$ in relation to the control sample (without inhibitor).

\subsubsection{Inhibition Kinetics of PHTI}

The kinetic measurements of trypsin inhibition by PHTI were conducted according to Dias et al. [19], with some modifications. $0.4 \mathrm{~mL}$ of PHTI $(0-10 \mathrm{nM})$ was incubated with various concentrations of BAPNA $(0.15,0.2,0.25,0.3,0.35,0.4$, and $0.45 \mathrm{mg} / \mathrm{mL})$ at $37^{\circ} \mathrm{C}$. The reaction was initiated by adding $1 \mathrm{~mL}$ of trypsin $(0.2 \mathrm{mg} / \mathrm{mL}$ in $1 \mathrm{mM} \mathrm{HCl})$, and was stopped after $10 \mathrm{~min}$ by the addition of $1 \mathrm{~mL}$ of 33\% $(v / v)$ acetic acid. All data were determined at the initial of the reaction. The absorbance was measured at $410 \mathrm{~nm}$. A Lineweaver-Burk plot was obtained by the reciprocal of the rate of the enzyme reaction $(1 / \mathrm{v})$ versus the reciprocal of the substrate concentration $(1 /[\mathrm{S}])$ in the absence and presence 
of PHTI. The inhibition constant (Ki) was determined according to Dixon [40]. A Ki value was obtained by the intersection of the lines at the $x$-axis, corresponding to the different substrate concentrations.

\subsubsection{Stability Studies}

The thermal stability of PHTI was determined by incubating PHTI $(0.25 \mathrm{mg} / \mathrm{mL})$ at different temperatures $\left(20-100{ }^{\circ} \mathrm{C}\right)$ for $30 \mathrm{~min}$. Then, samples were cooled to room temperature before the remaining activities were tested as described above. The PHTI stability at different $\mathrm{pH}$ was evaluated by dissolving PHTI in different buffers ( $\mathrm{pH} 2-10)$, and were incubated at room temperature for $1 \mathrm{~h}$. The remaining activities were then measured. The effects of metal ions on PHTI were also evaluated. PHTI was treated with various ions $\left(\mathrm{Al}^{3+}, \mathrm{Fe}^{3+}, \mathrm{Ba}^{2+}, \mathrm{Zn}^{2+}, \mathrm{Mn}^{2+}, \mathrm{Cu}^{2+}, \mathrm{K}^{+}\right.$, and $\left.\mathrm{Na}^{+}\right)$for $1 \mathrm{~h}$, then the remaining activities were determined as described above. The residual activity (\%) was calculated by taking the activity in the control (where PHTI was without any treatments) as $100 \%$.

\subsubsection{Steady-State Fluorescence}

Emission spectra of PHTI were obtained using a 970 CRT spectrophotometer (Jingke, Shanghai, China) and the samples were irradiated at an excitation wavelength of $295 \mathrm{~nm}$ and emission wavelengths were recorded from $290-400 \mathrm{~nm}$. Changes of the intrinsic fluorescence spectra of the purified PHTI $(0.25 \mathrm{mg} / \mathrm{mL}, 1 \mathrm{~mL})$ were recorded by addition of micro aliquots of $\mathrm{FeCl}_{3}(10 \mathrm{mmol} / \mathrm{L})$ to obtain final concentrations of $\mathrm{Fe}^{3+}$ ranging from 0 to $100 \mu \mathrm{M}$. For further investigation of the effect of $\mathrm{Fe}^{3+}$ ions on conformation of PHTI, the synchronous fluorescence spectra were conducted at the wavelength interval $(\Delta \lambda)$ of 15 and $60 \mathrm{~nm}$, respectively.

\subsection{Antifungal Activity}

\subsubsection{Filter Paper Method}

The antifungal activity of PHTI was first evaluated by the filter paper method, as described by Hong et al. [41], with some modifications. The activated mycelium was picked and placed in the center of sterile potato dextrose agar plates and cultured at $28^{\circ} \mathrm{C}$ for $72 \mathrm{~h}$. An aliquot of PHTI was introduced to each filter paper disk $(0.6 \mathrm{~cm}$ in diameter), placed about $0.5 \mathrm{~cm}$ away from the edge of the fungal colony. The plates were incubated for another $24 \mathrm{~h}$ until the mycelia enveloped the blank filter paper disks.

\subsubsection{Growth Kinetics Assay}

For the experimental work, the mother cultures of fungi were prepared by inoculating the fungi from PDA to PDB medium, and then were incubated at $180 \mathrm{rpm}, 28^{\circ} \mathrm{C}$ for $72 \mathrm{~h}$. The fungi were treated with 0 and $0.5 \mathrm{mM}$ PHTI in a 96 well microplate and the absorbance of each well was monitored at $1 \mathrm{~h}$ intervals at $600 \mathrm{~nm}$ using a Microplate reader. Besides, the absorbance at $260 \mathrm{~nm}$ in the supernatant was measured for determination of the nucleic acid leakage. The assay was tested thrice on different days [42].

\subsubsection{SEM Analysis}

The fungi were treated with 0 and $0.5 \mathrm{mM}$ of PHTI for $6 \mathrm{~h}$, and were fixed in $2.5 \%$ glutaraldehyde for $12 \mathrm{~h}$, washed with $0.9 \% \mathrm{NaCl}$ for $10 \mathrm{~min}$, and then dehydrated in ethanol gradient $(20 \%, 50 \%$, $80 \%, 100 \%)$. Fungi samples $(5 \mu \mathrm{L})$ were dropped on the monocrystalline silicon and dried for $1 \mathrm{~h}$, then the samples were coated by gold and the surface morphologies of the fungi were visualized under SEM [43].

\subsubsection{Fluorescence Based Fungi Viability Assay}

The fungi were treated with 0 and $0.5 \mathrm{mM}$ of PHTI for $6 \mathrm{~h}$, respectively. Fungal viability was evaluated using a LIVE/DEAD BacLight viability kit (L17012, Thermo Scientific, Waltham, MA, USA) 
and imaging was done by a Laser scanning confocal microscope (AI, Nikon Instruments Inc., Tokyo, Japan) [44].

\subsection{Statistical Analysis}

All data are presented as means \pm standard deviations (SDs) of three independent experiments. Statistical analysis was done using the Student's $t$ test. A value of $p<0.05$ was considered statistically significant.

\section{Conclusions}

In summary, a Kunitz-type trypsin inhibitor PHTI with a molecular mass of 20.5 kDa was purified from fresh roots of Pseudostellaria heterophylla. PHTI possessed superior thermal and $\mathrm{pH}$ stability. $\mathrm{Fe}^{3+}(20 \mathrm{mM})$ could significantly inactivate PHTI through changing its conformation. Besides, PHTI exhibited antifungal activity against phytopathogens of P. heterophylla by disrupting the cell membrane integrity of fungi. The present study extends the research on proteins of $P$. heterophylla, suggesting an exploitable potential for this class of antifungal protein in the food industry and agriculture.

Author Contributions: Conceptualization, X.C., N.F. and S.W.; Methodology, X.C. and X.X.; Validation, X.C., X.X., N.F. and S.W.; Formal Analysis, X.C. and X.X.; Investigation, X.X. and X.C.; Resources, S.W.; Data Curation, X.C.; Writing-Original Draft Preparation, X.X. and X.C.; Writing-Review \& Editing, S.W.; Funding Acquisition, S.W.

Funding: This work was supported by National Key R\&D Program of China (No. 2016YFD0400202), National Natural Science Foundation of China (No. 31771922).

Conflicts of Interest: The authors declare no conflict of interest.

\section{References}

1. Jamal, F.; Singh, D.; Khan, M.Y. Serine protease inhibitors in plants: Nature's arsenal crafted for insect predators. Phytochem. Rev. 2013, 12, 1-34. [CrossRef]

2. Bhattacharyya, A.; Mazumdar, S.; Leighton, S.M.; Babu, C.R. A Kunitz proteinase inhibitor from Archidendron ellipticum seeds: Purification, characterization, and kinetic properties. Phytochemistry 2006, 67, 232-241. [CrossRef] [PubMed]

3. Fang, E.F.; Hassanien, A.A.; Wong, J.H.; Bah, C.S.; Soliman, S.S.; Ng, T.B. Purification and modes of antifungal action by Vicia faba cv. Egypt trypsin inhibitor. J. Agric. Food Chem. 2010, 58, 10729-10735. [CrossRef] [PubMed]

4. Wang, S.Y.; Rao, P.F. A leguminous trypsin-chymotrypsin inhibitor Limenin with antifungal activity from Phaseolus limensis. Eur. Food Res. Technol. 2010, 231, 331-338. [CrossRef]

5. Kennedy, A.R. Chemopreventive Agents: Protease Inhibitors. Pharmacol. Therap. 1998, 78, 167-209. [CrossRef]

6. Oliva, M.L.V.; Souza-Pinto, J.C.; Batista, I.F.C.; Araujo, M.S.; Silveira, V.F.; Auerswald, E.A.; Mentele, R.; Eckerskorn, C.; Sampaio, M.U.; Sampaio, C.A.M. Leucaena leucocephala serine proteinase inhibitor: Primary structure and action on blood coagulation, kinin release and rat paw edema11Dedicated to Prof. Hans Neurath. Biochim. Biophys. Acta 2000, 1477, 64-74. [CrossRef]

7. Confalonieri, M.; Allegro, G.; Balestrazzi, A.; Fogher, C.; Delledonne, M. Regeneration of Populus nigra transgenic plants expressing a Kunitz proteinase inhibitor (KTi3) gene. Mol. Breed. 1998, 4, 137-145. [CrossRef]

8. Rehman, S.; Aziz, E.; Akhtar, W.; Ilyas, M.; Mahmood, T. Structural and functional characteristics of plant proteinase inhibitor-II (PI-II) family. Biotechnol. Lett. 2017, 39, 647-666. [CrossRef] [PubMed]

9. Keilová, H.; Tomášek, V. Isolation and some properties of cathepsin D inhibitor from potatoes. Collect. Czech. Chem. Commun. 1976, 41, 489-497. [CrossRef]

10. Haq, S.K.; Atif, S.M.; Khan, R.H. Protein proteinase inhibitor genes in combat against insects, pests, and pathogens: Natural and engineered phytoprotection. Arch. Biochem. Biophys. 2004, 431, 145-159. [CrossRef] [PubMed] 
11. Batista, I.F.C.; Oliva, M.L.V.; Araujo, M.S.; Sampaio, M.U.; Richardson, M.; Fritz, H.; Sampaio, C.A.M. Primary structure of a Kunitz-type trypsin inhibitor from Enterolobium contortisiliquum seeds. Phytochemistry 1996, 41, 1017-1022. [CrossRef]

12. Azarkan, M.; Martinez-Rodriguez, S.; Buts, L.; Baeyens-Volant, D.; Garcia-Pino, A. The plasticity of the $\beta$-trefoil fold constitutes an evolutionary platform for protease inhibition. J. Biol. Chem. 2011, 286, 43726-43734. [CrossRef] [PubMed]

13. PCCN. Chinese Pharmacopoeia, 2015 ed.; Chemical Industry Publishing House: Beijing, China, 2015.

14. Wong, C.K.; Leung, K.N.; Fung, K.P.; Pang, P.K.; Choy, Y.M. Tumor necrosis factor eliciting fractions separated from Pseudostellaria heterophylla. Int. J. Immunopharmacol. 1994, 16, 271-277. [CrossRef]

15. Wong, C.K.; Leung, K.N.; Fung, K.P.; Choy, Y.M. The immunostimulating activities of anti-tumor polysaccharides from Pseudostellaria heterophylla. Immunopharmacology 1994, 28, 47-54. [CrossRef]

16. Wang, Z.; Liao, S.G.; He, Y.; Li, J.; Zhong, R.F.; He, X.; Liu, Y.; Xiao, T.T.; Lan, Y.Y.; Long, Q.D.; et al. Protective effects of fractions from Pseudostellaria heterophylla against cobalt chloride-induced hypoxic injury in $\mathrm{H} 9 \mathrm{c} 2$ cell. J. Ethnopharmacol. 2013, 147, 540-545. [CrossRef] [PubMed]

17. Tan, N.H.; Zhou, J. Plant Cyclopeptides. Chem. Rev. 2006, 106, 840-895. [CrossRef] [PubMed]

18. Wang, H.X.; Ng, T.B. Concurrent isolation of a Kunitz-type trypsin inhibitor with antifungal activity and a novel lectin from Pseudostellaria heterophylla roots. Biochem. Biophys. Res. Commun. 2006, 342, 349-353. [CrossRef] [PubMed]

19. Dias, L.P.; Oliveira, J.T.A.; Rocha-Bezerra, L.C.B.; Sousa, D.O.B.; Costa, H.P.S.; Araujo, N.M.S.; Carvalho, A.F.U.; Tabosa, P.M.S.; Monteiro-Moreira, A.C.O.; Lobo, M.D.P.; et al. A trypsin inhibitor purified from Cassia leiandra seeds has insecticidal activity against Aedes aegypti. Process Biochem. 2017, 57, $228-238$. [CrossRef]

20. Lopes, J.L.; Valadares, N.F.; Moraes, D.I.; Rosa, J.C.; Araújo, H.S.; Beltramini, L.M. Physico-chemical and antifungal properties of protease inhibitors from Acacia plumosa. Phytochemistry 2008, 70, 871-879. [CrossRef] [PubMed]

21. Oliva, M.L.V.; Silva, M.C.C.; Sallai, R.C.; Brito, M.V.; Sampaio, M.U. A novel subclassification for Kunitz proteinase inhibitors from leguminous seeds. Biochimie 2010, 92, 1667-1673. [CrossRef] [PubMed]

22. Oddepally, R.; Sriram, G.; Guruprasad, L. Purification and characterization of a stable Kunitz trypsin inhibitor from Trigonella foenum-graecum (fenugreek) seeds. Phytochemistry 2013, 96, 26-36. [CrossRef] [PubMed]

23. Macedo, M.L.; Garcia, V.A.; Md, F.; Richardson, M. Characterization of a Kunitz trypsin inhibitor with a single disulfide bridge from seeds of Inga laurina (SW.) Willd. Phytochemistry 2007, 68, 1104-1111. [CrossRef] [PubMed]

24. Jamal, F.; Pandey, P.K.; Singh, D.; Ahmed, W. A Kunitz-type serine protease inhibitor from Butea monosperma seed and its influence on developmental physiology of Helicoverpa armigera. Process Biochem. 2015, 50, 311-316. [CrossRef]

25. Dabhade, A.R.; Mokashe, N.U.; Patil, U.K. Purification, characterization, and antimicrobial activity of nontoxic trypsin inhibitor from Albizia amara Boiv. Process Biochem. 2016, 51, 659-674. [CrossRef]

26. de Oliveira, C.F.R.; Vasconcelos, I.M.; Aparicio, R.; Freire, M.d.G.M.; Baldasso, P.A.; Marangoni, S.; Macedo, M.L.R. Purification and biochemical properties of a Kunitz-type trypsin inhibitor from Entada acaciifolia (Benth.) seeds. Process Biochem. 2012, 47, 929-935. [CrossRef]

27. Cruz, A.C.B.; Massena, F.S.; Migliolo, L.; Macedo, L.L.P.; Monteiro, N.K.V.; Oliveira, A.S.; Macedo, F.P.; Uchoa, A.F.; Grossi de Sá, M.F.; Vasconcelos, I.M.; et al. Bioinsecticidal activity of a novel Kunitz trypsin inhibitor from Catanduva (Piptadenia moniliformis) seeds. Plant Physiol. Biochem. 2013, 70, 61-68. [CrossRef] [PubMed]

28. Liu, D.Z.; Lu, Y.L.; Cheng, H.C.; Hou, W.C. Immobilized zinc affinity chromatography of pectin hydroxamic acids for purification of trypsin inhibitors from soybean and sweet potato. J. Agric. Food Chem. 2005, 53, 10219-10223. [CrossRef] [PubMed]

29. Bijina, B.; Chellappan, S.; Basheer, S.M.; Elyas, K.K.; Bahkali, A.H.; Chandrasekaran, M. Protease inhibitor from Moringa oleifera leaves: Isolation, purification, and characterization. Process Biochem. 2011, 46, 2291-2300. [CrossRef]

30. Zhang, H.-X.; Huang, X.; Mei, P.; Gao, S. Interaction between glyoxal-bis-(2-hydroxyanil) and bovine serum albumin in solution. J. Solut. Chem. 2008, 37, 631-640. [CrossRef] 
31. Zhang, X.; Kou, Z.; Shi, Y.; Zhu, J. Investigation on effect of fluorescence enhancement of Danshensu-BSA system by synchronous fluorescence spectrometry. J. Instrum. Anal. 2011, 30, 444-447.

32. Sang, W.; Xiong, J.; Song, B.; Li, X.; Lian, Q.; Zhang, Z.; Xia, Z. Investigation and prevention of fungal diseases of Radix Pseudoxtellariae in Guizhou Province. J. Anhui Agric. Sci. 2006, 34, 3314-3316.

33. Nwozo, S.O.; Iwuoha, E.I.; Waryo, T.; Kgarebe, B. Isolation, partial purification and characterization of antifungal trypsin inhibitor protease from the seed of Blighia sapida K.D. Koenig (Ackee). Afr. J. Biotechnol. 2014, 13, 2996-3007. [CrossRef]

34. Luo, X.-M.; Xie, C.-J.; Wang, D.; Wei, Y.-M.; Cai, J.; Cheng, S.-S.; Yang, X.-Y.; Sui, A.-P. Psc-AFP from Psoralea corylifolia L. overexpressed in Pichia pastoris increases antimicrobial activity and enhances disease resistance of transgenic tobacco. Appl. Microbiol. Biotechnol. 2017, 101, 1073-1084. [CrossRef] [PubMed]

35. Lin, P.; $\mathrm{Ng}$, T.B. A stable trypsin inhibitor from Chinese dull black soybeans with potentially exploitable activities. Process Biochem. 2008, 43, 992-998. [CrossRef]

36. Cheung, A.H.; Wong, J.H.; Ng, T.B. Trypsin-chymotrypsin inhibitors from Vigna mungo seeds. Protein Peptide Lett. 2009, 16, 277-284. [CrossRef]

37. Laemmli, U.K.; Favre, M. Gel electrophoresis of proteins. J. Mol. Biol. 1973, 80, 575-599. [CrossRef]

38. Zhou, Z.M.; Yang, F.; Cao, W. Comparison of different methods for PAS staining of renal biopsy tissue sections. J. South. Med. Univ. 2012, 32, 371-373.

39. Birk, Y. Trypsin and chymotrypsin inhibitors from soybeans. Method. Enzymol. 1976, 45, 700-707.

40. Dixon, M. The determination of enzyme inhibitor constants. Biochem. J. 1953, 55, 170-171. [CrossRef] [PubMed]

41. Hong, Y.; Cai, X.; Shao, B.; Jing, H.; Wang, S.; Rao, P. Isolation of a thermostable trypsin inhibitor with exploitable potential. Eur. Food Res. Technol. 2013, 237, 457-465. [CrossRef]

42. Prince, A.; Sandhu, P.; Ror, P.; Dash, E.; Sharma, S.; Arakha, M.; Jha, S.; Akhter, Y.; Saleem, M. Lipid-II independent antimicrobial mechanism of nisin depends on its crowding and degree of oligomerization. Sci. Rep. 2016, 6, 37908. [CrossRef] [PubMed]

43. Shagaghi, N.; Bhave, M.; Palombo, E.A.; Clayton, A.H.A. Revealing the sequence of interactions of PuroA peptide with Candida albicans cells by live-cell imaging. Sci. Rep. 2017, 7, 43542. [CrossRef] [PubMed]

44. Macedo, M.L.; Ribeiro, S.F.; Taveira, G.B.; Gomes, V.M.; de Barros, K.M.; Maria-Neto, S. Antimicrobial Activity of ILTI, a Kunitz-Type Trypsin Inhibitor from Inga laurina (SW.) Willd. Curr. Microbiol. 2016, 72, 538-544. [CrossRef] [PubMed]

Sample Availability: Samples of the compounds are not available from the authors.

(C) 2018 by the authors. Licensee MDPI, Basel, Switzerland. This article is an open access article distributed under the terms and conditions of the Creative Commons Attribution (CC BY) license (http://creativecommons.org/licenses/by/4.0/). 